\title{
Research on the current situation and construction of college teaching quality assurance system in Jilin Province
}

\author{
Zhao Xianglian \\ Center for Teaching and Learning Development \\ Jilin Agricultural University \\ Changchun, China
}

\author{
Wang Shuli \\ Center for Teaching and Learning Development \\ Jilin Agricultural University \\ Changchun, China
}

\author{
Zhou Jianzhong \\ Center for Teaching and Learning Development \\ Jilin Agricultural University \\ Changchun, China \\ 15387186@qq.com
}

\begin{abstract}
Over the years, the whole society is increasingly concerning about the talent training goal of higher education and its teaching quality with the rapid growth of the higher learning education. This paper aims to study some problems existing in the teaching quality assurance system in several colleges of Jilin province in the perspective of total quality management theory and introduce its important principles into the research of improving teaching quality assurance system; by the way of study how to reconstruct teaching quality assurance system based on total quality management and also focus on the establishment of microcosmic system, then to prompt the education administrative department at all levels and its personnel to positively respond to the quality management systematization and to meet together the chances and challenges in higher teaching quality management brought by the accelerated popularization of modern education in $21^{\text {st }}$ century .
\end{abstract}

Keywords-quality assurance; current situation; system construction

\section{CuRrent Situation Of The Teaching System IN JILIN PROVINCE}

The research group chose 8 colleges and universities in Jilin Province, issued a student questionnaire, 91 teaching management personnel and teaching teachers in the classroom. The questionnaire was designed on the quality of teaching staff, teaching quality, teaching management level, teaching hardware investment, practice training activity organization, professional course setting and so on. Students answered the question enthusiastically, there are 850 students participated in the survey, 840 valid questionnaires, the effective rate was $98.8 \%$. Most people also have to fill out their own opinions; the questionnaire to a large extent can reflect the school's overall teaching management. The results and analysis are as

Project: The research and practice of vocational education teaching system in Jilin Province Education Department "five eleven" ("practice oriented" curriculum mode. Topic host: Zhou Jianzhong. (Subject number: [2008] 157th) follows.

\section{A. The Lack of Complete Teaching Quality Assurance System}

Teaching management staff is generally considered to have no complete teaching quality assurance system. $95 \%$ the reason is that the construction of the school teaching quality assurance system is to enhance the recognition of the community, improve teaching quality. 55\% teaching management staff said the school did not complete the teaching quality assurance system, $35 \%$ of the teaching management staff said, even though the emphasis for teaching quality assurance system, also the school in the assessment of the education department, the existing organizational structure, will have to make a summary, expansion, which will be the general title "teaching quality assurance system construction", There is no special organization and part of the school departments work separately, lack of communication, especially for students to put out the basic facilities and teaching equipment, replacement, etc., due to the constraints of teaching funds is difficult to achieve.[1]

\section{B. Teaching Information is not Smooth}

To establish a scientific and comprehensive teaching information management system is an important manifestation of improving teaching management level. For the school teaching management information, 23 think it smooth, 30 think it not smooth, in a certain range of information communication is less, the degree is weak, cannot reach the expected effect of the information.

\section{Classroom Teaching Quality is Low, the Teaching Staff Cannot Adapt to The Development of Higher Education}

In the 840 valid questionnaires, the students were satisfied with the quality of the teachers' teaching, $25 \%$ were satisfied, 
$6 \%$ were pretty satisfied and $4 \%$ were not satisfied. At present, there are some difficulties in classroom teaching, the first one is to reduce the curriculum hours, and the second one is the rapid development of modern science and technology, and the third one is difficulty of increasing the content of classroom teaching. The forth one is the lack of interest in learning.[2]

\section{Scientific and Technological Innovations are Fewer, the Lack of Experimental Training Equipment}

"Do you take part in all kinds of scientific and technological innovation activities", For this question, $11 \%$ answer is regular, $60 \%$ answer is occasionally, 29\% answer is never. Students said they are willing to participate in such activities, but the practice of training and other activities of the device is a bit outdated, and the venue is small, the lack of necessary experimental training links. Due to the shortage of funds in higher vocational education and government funds, the poor conditions of running higher vocational colleges, "with yesterday's equipment and technology, to train people today". In the survey, $31 \%$ of the teachers think that teaching equipment has been updated, and the operation is good. $69 \%$ of the teachers think that teaching equipment is aging, which needs to be renewed, which directly affects the quality of vocational education, which greatly restricts the rapid development of higher vocational education.

\section{TAKING VARIOUS MEASURES TO BUILD A TEACHING QUALITY ASSURANCE SYSTEM}

Using the idea of the quality management (TQC) system standard, according to the system theory, information theory, control theory and teaching quality, the teaching quality assurance system includes five systems: teaching quality management concept, teaching quality management system, quality management system, teaching quality guarantee system, and teaching quality control system. They constitute a closed loop of teaching quality assurance system,which is in Colleges and Universities.

\section{A. Teaching Quality Management Concept oriented System}

According to the present situation of teaching quality management in Colleges and universities, there are many problems in objective, reasonable and scientific. Therefore, it is necessary to improve teaching quality and market competition ability. It is necessary to import the international advanced quality management concept as soon as possible to construct the scientific management framework and to develop strict operation procedure.

\section{B. Teaching Quality Management File System}

Teaching quality management file is actually teaching management rules and regulations, is the standard of the teaching management work, a stable teaching order, the implementation of the teaching plan, the completion of the teaching task, improves the quality of teaching effective protection. We should be in line with the principle of peopleoriented, keeping pace with the times, develop or improve the relevant rules and regulations. This system contains the program file (referring to the work flow or process), operating file (refer to the implementation of views, rules, management methods and regulations and other system documents) and record documents (refer to the implementation process of the relevant records, such as the implementation of the situation, effect, improvement measures, etc.).

The favorable system files in the promotion - good teaching style and the formation of the style of study in order to ensure the quality of personnel training that play an important role in the implementation of scientific, institutionalized, standardized management, a good education work to lay a certain foundation. However, with the continuous changes in the demand for talents and the development of higher education, the new problems and new situations in the teaching management should be adjusted. They should be based on the relevant laws and regulations of the state, the Ministry of education to implement the spirit of the relevant documents, in a wide range of views on the basis of the above, the timely development, modification and improvement.[3]

\section{Teaching Quality Management Organization System}

Teaching quality management organization refers to the needs of teaching management.[4] The organization of the internal division of certain level set up a certain level, with a certain degree of power, to achieve a certain degree of responsibility, and to improve the teaching quality, training qualified personnel to determine the root of teaching management organization, coordination, control and other management functions. The Supreme Court school should follow the streamlined and efficient, clear responsibility, coordinated operations, information flow, full participation principle, the establishment of teaching management system.

The school is at the highest level, decision-making, comprehensive coordination and comprehensive management. The middle should be the implementation of the highest level of decision, to play the initiative of the Department, with the actual, make specific arrangements. The teaching and research group (room) is the basic unit of the school teaching, the research group is responsible for the organization and management of the teaching and research activities of the group.

Improve the teaching quality management organization system is to establish and improve the teaching network, clear communication channels, so that the upper and lower communication, about collaboration, ensure the consistency of the pace of thinking and action, is the scientific process of teaching management. Only in this way, can the teaching quality management organization's advantage, to get the effective play, and make it step by step on the track of standardization.

\section{Teaching Condition Guarantee System}

Condition guarantee is to ensure that the system's input, the system's input guarantee is to ensure the quality of teaching and system operation of the premise, the higher vocational college teaching quality assurance system of the operation needs of all aspects of investment.

The first is the input of teachers. Optimizing the structure of teachers, cultivating and establishing "double", adapting to the teaching staff and adapting to the requirements of higher vocational education, we should pay special attention to strengthen teachers, especially young teachers "teaching 
business, establish teacher training and qualification requirements, and promote teachers' teaching level.

Second is the investment of teaching management personnel. We should pay attention to the improvement of the quality of teaching management staff, improve the level and level of training, and continuously optimize the teaching management team; we must establish the corresponding incentive and restraint mechanisms. To establish a complete teaching management rules and regulations of rewards and penalties system make the teaching activities and teaching management work and strive to, executable, stimulate enthusiasm for the work of teaching management personnel, so as to ensure the orderly conduct of teaching and teaching management specification.

Finally, it is the investment of teaching funds. The funds used in the discipline construction, key disciplines, to ensure the teaching of funding, scientific research funding, management of the reasonable use of funds.

\section{E. Teaching Quality Monitoring System}

The improvement of the teaching quality monitoring system is the key factor to ensure the effective monitoring, the monitoring system of higher education teaching quality is mainly based on personnel training scheme, and the supervision and control of the two levels of the teaching system, the students information system, the teaching inspection system, the quality of the students, and the teaching evaluation system. Quality is formed in the process, the key to improve the quality of teaching lies in the implementation of the rules and regulations of various teaching links. The teaching process monitoring throughout the lesson preparation, classroom teaching, experimental teaching, exercise and guidance and answering questions, test and examination, educational probation (novitiate), trial teaching, education practice (professional practice), the whole process of the graduation thesis (Design) and the defense of the whole teaching activities, the teaching process of the whole monitoring is the construction of teaching quality monitoring system of the central part of the. Through the college and department two level system of the teaching process dynamic monitoring, the information timely and effective feedback to the teachers, to help teachers to improve teaching methods, improve teaching level, to promote the teaching quality continuously improve, so as to achieve the goal of talents cultivation and the teacher's own growth.

\section{CONCLUSION}

The establishment of teaching guarantee system should be fully reflected the training goal of applied talents, cultivate students ' ability to analyze and solve practical problems, learning capac ity, professionalism; Requires to establish the concept of teach ing evaluation on the orientation of abilities during the test and inspection; Focus on teachers and students in the process of pro fessional development progress and self-improvement.

\section{REFERENCES}

[1] Bai Ling, Wang Jian. Based on the analysis of the three major elements of vocational education curriculum model status and development direction of the Journal of Hubei Correspondence University, 2014 (10)

[2] Yang Xuhui, Huang Qiuming, Wang Zheng. Research on the quality assurance system of Higher Vocational Curriculum [J]. China high education research, 2004 (11)

[3] Liu Feng, cold tillian. To improve the practice teaching quality of Higher Vocational College of $[\mathrm{J}]$. experimental technology and management, 2014 (08)

[4] $\mathrm{Hu}$ Yujie, where is the current situation of preschool teacher training model -- from the perspective of the 2014 (12) of the [J]. education and education forum, which has been obtained from the training of teachers in the UK, US and Japan 